\title{
The inmate as a victim of the rise in the incarceration rate and the perception of insecurity in western society. A particular analysis of the Chilean case.
}

\author{
El interno como víctima del aumento del índice de \\ encarcelamiento y la percepción de inseguridad en la \\ sociedad occidental. Análisis particular del caso chileno.
}

\author{
Silvio Cuneo ${ }^{1}$ \\ Universidad Central de Chile - Santiago/Chile \\ silvio.cuneo@ucentral.cl \\ http://orcid.org/0000-0003-1072-745X
}

\begin{abstract}
AвSTRACt: Often, the discussion about the victim in the penal process recognizes only the crime victim and doesn't take into consideration that the inmate, the person deprived of liberty, might also be a victim of the criminal justice system. This paper analyses the issue of mass imprisonment with particular attention to the Chilean case. The excessive and selective use of the deprivation of freedom has become a controlling tool, filling our prisons with those excluded from society. After a general analysis, we will investigate the causes of mass imprisonment: the dismantling of the Welfare State (followed by tougher punishment) and punitive populism (result of a vindictive demagogic attitude). We believe that the selection by which it operates, the effects that it produces and the resulting advantages for the privileged minorities make this not only illegitimate but also intolerable in a democratic society. We will conclude with a realistic proposal, an alternative to mass imprisonment, compatible with respect for human dignity.
\end{abstract}

1 Académico de la Universidad Central de Chile. Doctor en Derecho por la Universitat Pompeu Fabra y la Università degli Studi di Trento. Entre sus libros destacan: "Cárceles y pobreza. Distorsiones del populismo penal" (2018), "El encarcelamiento masivo" (2017), "La cárcel moderna. Una crítica necesaria” (2017) y "Cine y Derecho penal" (2010). 
KeY words: inmates; punitive populism; vindictive demagogic attitude; social state; penal state.

RESUMEN: Normalmente cuando se habla de la víctima del proceso penal se piensa en la víctima del delito y se olvida que la principal víctima es el privado de libertad. Este trabajo analiza e problema del aumento del encarcelamiento con especial atención al caso chileno. El uso excesivo y selectivo de la pena privativa de libertad la ha transformado en un mecanismo de control, llenando las cárceles de marginados. Tras un análisis general de las principales causas del aumento del encarcelamiento: el desmantelamiento del Estado social (acompañado de una mayor punitividad) y el populismo punitivo (como resultado de un discurso demagógico vindicativo), se analizará la selectividad con la que opera, los efectos que produce y las ventajas que supone para grupos muy minoritarios. Todo lo anterior hace del encarcelamiento masivo algo ilegítimo e intolerable en una sociedad democrática. Concluye este trabajo con propuestas alternativas y factibles al encarcelamiento masivo, compatibles con el respeto por la dignidad humana.

Palabras clave: personas privadas de libertad; populismo punitivo; demagogia vindicativa; Estado social; Estado penal.

SUMmary: 1. Introduction. 2. Modern prison. 3. The effects of modern prison. 4. Mass imprisonment. 5. Causes of mass imprisonment. 6. Imposition of a hegemonic attitude. 7. The Chilean situation. Conclusions. References.

\section{INTRODUCTION}

The title of this paper suggests two aspects: first, that it's also true that the victim of the penal process is not only the crime victim but also the individual who must suffer the consequences of the punitive system. On the other hand, that a major cause of mass imprisonment is the perception of insecurity.

Concerning the first aspect seems appropriate to recall Giorgio del Vecchio stating that the history of punishment is as dishonorable for human kind as the history of crime. In this sense criminal law becomes more detrimental than crime itself. Likewise, once stated the ineffectiveness 
of criminal law to control crime, makes sense to keep it merely as a management system for poverty. ${ }^{2}$

The second aspect, closely related to the first one, is the one that I'll explain in the following paragraphs, aiming to explain how an exponential increasing of selective and classist incarceration takes place, fed by perception of insecurity developed and increased by the media.

We can say that perception does not always correlate with reality, meaning that perception can be different from reality. Crime is a real (not-invented) problem, but is perceived as being much more serious than it actually is. This distortion is generated by different factors, but it is mainly due to the majority of people not informing themselves by reading criminal statistics or scientific journals of criminology, while instead they build their conception of crime and criminality from the mass media and in particular from television.

The latter (as indeed every mass media) tries to capture the attention of the viewer: violent and cruel images serve this purpose and the crime (particularly the violent one) is overexposed, creating a much bigger and distorted image of violent crime.

This distorted view of crime generates fear and fear, the enemy of reason, opens the floodgates for opportunistic politicians to exploit it, to present themselves as guardians of victims of violent crimes.

Given that mass media are not able to, nor interested in, explaining the complexity of crime, they prefer offering a simple and coarse "explanation", with a no alternative solution according to which you are either on the side of the victim or that of the criminal. ${ }^{3}$

In this climate of fear, punitive populism generates important electoral gains and punitive legislation is the result of the vindictive demagogic attitude.

Very generally speaking, we can simplify the problem as follows:

2 Cuneo, Silvio, Cárceles y Pobreza. Distorsiones del populismo penal, Santiago de Chile: Uqbar editores, 2018.

3 Garland, David, The Culture of Control. Crime and Social Order in Contemporary Society, Chicago: University of Chicago Press, 2001; Cavadino, Michael, Cavadino, Mick and Dignan, James. Penal systems: A comparative approach, London: Sage, 2005. 
Magnified perception of crime $\rightarrow$ fear $\rightarrow$ more punitive legislation

However, this explanation is somewhat superficial and indeed simplistic and certainly does not suffice to account for a very complex phenomenon, namely that of mass imprisonment.

In order to understand, study, and attempt to explain these phenomena, single explanations fall far short of our purpose.

The multi causality of mass imprisonment demands studying this phenomenon by adopting an interdisciplinary method (or methods). However, it is difficult to comprehend the diverse causes and the risk is real of appearing naïve, as it not possible to conduct - as would be appropriate - a sociological, criminological, psychological, penological, juridical, philosophical, etc. analysis.

On the other hand, when we explain or try to understand this phenomenon, there is a tendency to split the causes (non-mediated causes, on the one hand, meaning laws or case- laws; mediated causes, on the other hand, meaning those that deal with context: punitive populism, economic system, etc.). Nevertheless, this breakdown forces us to separate a tangled reality. The split of the analysis, even if it leads to a better comprehension, prevents us from grasping the dynamism of reality.

More often than not, the jurist does not carry out this analysis, but we are convinced that it is a "must", especially for criminal jurists, in order to enter the dark world of the reality of punishment. Over 250 years ago, Beccaria already urged us to see criminal law as a two-faced coin: crime and punishment.

However, it seems that criminal jurists have forgotten punishment: manuals, treatises and various monographies are devoted almost exclusively to the analysis of the theory of crime, in an increasingly abstract manner, omitting its repercussion on the punishment. The majority of criminal jurists never go as far as the reality of the punishment. Prison and the silence that surrounds this issue end up legitimizing a space that is a legal void or its denial. In this way, prison becomes a space without justice, forgotten by criminal jurists. ${ }^{4}$

4 The objection that Italian criminal jurists might raise when citing the vast literature generated by the Torregiani sentence actually confirms our thesis: before this particular ruling the number of existing documents written by 
In this paper, we offer our point of view regarding mass imprisonment in the United States and the export of the overall punitive system, with particular regards to Chile. Before undertaking an analysis of mass imprisonment, we will briefly discuss modern prison as a punishment.

\section{MODERN PRISON}

Just over 200 years after its birth, modern prison, notwithstanding the criticism that has always accompanied it, contradicts entire libraries that speak of a crisis - indeed, a perennial crisis - of an obsolete and indefensible institution. Figures are impressive and, despite a slight decrease in recent years in some countries, imprisonment is, in the XXI century, more present than ever.

The rise in the number of detainees demonstrates that our society has an increasing tendency to imprison large human groups.

The prison crisis (discussed, among others, by Foucault) ${ }^{5}$ is rather the crisis of a debate that seeks its legitimation that, in any case, does not seem to influence either its existence or its expansion.

Lately, the debate has become more sincere: prison is presented as a tool to neutralize enemies and its main purpose is to remove them from circulation.

Since 11 September 2001, the use of a bellicose political language has emerged. The war on terrorism is to be added to the wars against crime, drugs and pedophilia.

However, those that fill prisons are not dangerous pedophiles, nor terrorist leaders, nor the major drug traffickers.

Nevertheless, the United States prison system ${ }^{6}$ has been imitated - and even imposed - and expanded rapidly in Latin America and in particular in Chile.

criminal jurists about prison was very limited and that sentence is not the result of a national desire as it was issued by an international court such as the ECHR. Cfr. M. Ruotolo, Marco (a cura di), Il senso della pena. Ad un anno dalla sentenza Torregiani della Corte EDU. Napoli: Editoriale Scientifica: 2014.

5 Foucault, Michael, Vigilar y castigar: nacimiento de la prisión, México: Siglo XXI. 2002, (Translated from French by Garzón del camino, Aurelio).

6 Italian jurists have learned to recognize its details thanks to the book Grande, Elisabetta, Il terzo strike. La prigione in America, Palermo: Sallerio Editore, 
The economic structure in Chile facilitates the differentiation of people and the enemies are easily recognizable. Ugly, dirty and bad - to cite a film directed by Ettore Scola - are the favourite "clients" crowding the prisons of Latin America (although we could argue that is the case all over the world).

Faced with this bloated phenomenon and the win back of prison in the XXI century, a key question arises: why does modern society imprison human beings so massively?

Along with this question, others arise: why are prisons mainly populated by the poorer and the marginalized?

We may not be able to fully answer these questions, but we can at least attempt to think about possible answers.

Let us begin with a more general question: why was prison created?

Traditionally it is believed that the birth of modern prison (prison as a punishment and not as a deprivation of liberty for other purposes) is the consequence of convictions being made more human and the rejection of cruel and inhuman punishment. ${ }^{7}$

Prison, according to this traditional theory, is a manifestation of the Enlightenment thought. However, this theory is challenged by other alternative theories.

Some (Foucault, Goffman, etc.), ${ }^{8}$ believe that prison represents a specific strategy of power that seeks the discipline and segregation of groups that may be troublesome for those in power. Therefore, used as a political strategy of control, prisons, mental hospitals, barracks, etc., are essential places in order to segregate large human groups that could be troublesome for those in power.

2007. The discussion presented in this article is strongly related to another recent piece of work by the same author: ID., Guai ai poveri. La faccia triste dell'America, Torino: Edizione GruppoAbele, 2017.

7 Guzmán Dálbora, José, La pena y la extinción de la responsabilidad penal, Santiago de Chile: Legal Publishing, 2008.

8 Foucault, Michael, Vigilar y castigar: nacimiento de la prisión, Mexico: Siglo XXI. 2002, (Translated from French by A. Garzón del Camino); Goffman, Erving, Internados. Ensayos sobre la situación social de los enfermos mentales, Buenos Aires: Amorrortu Editores, 1992, (Translated from English by M. Oyuela). 
Another theory of Marxist tradition links punishments (all types of punishments) to economic structures (among others: Rusche and Kirchheimer; Melossi and Pavarini). ${ }^{9}$ When convicts were needed, the punishment was prison; when important works were needed to develop the economy, punishment was envisaged for those very works. Prison, as a modern punishment, is therefore the consequence of a capitalist regime that tries to transform the lower classes into cheap and submissive labour.

As mentioned above, all those theories help to gain a better understanding of prison, but only with a multi- or pluri-causal analysis we can gain a better understanding of prison. Every single theory helps us understand only a smaller part of the complex phenomenon of imprisonment and mass imprisonment.

Foucault, for instance, outlines that behind imprisonment lies profit and control, but he is most likely wrong in not paying enough attention to the amount of irrationality underlying the very idea of prison. We cannot argue that prison per se - with its high costs - only represents a profit for the ruling class.

Foucault is wrong in basing his entire theory only from the point of view of control. On the other hand, we believe he is correct when he mentions that behind prison lies a controlling strategy, but not everything is control. Prison also exists for other reasons linked to the sensitivity of a precise historical period.

Traditional theory merely explains one factor and Foucault makes us realize how many gaps still exist in our analysis. However, Foucault's analysis exaggerates seeing control as an explanation for every aspect of the question.

Neo-Marxists also rely on a mono-causal analysis (the only cause is identified in the capitalist structure), but there are also reasons that derive from the change in the sensitivity of public opinion.

We can argue that modern society is not interested in the rights of convicts (argument that could be acceptable), but then again, our

9 Rusche, Georg, Kirchheimer, Otto, Pena y estructura social, Bogotà: Temis, 2004, (Translated from English by E. García Méndez); Melossi, Dario, Pavarini, Massimo, Carcere e fabbrica. Alle oringini del sistema penitenziario (XVI -XIX secolo). Bologna: Il Molino, 1978. 
sensitivity does not allow us to hang a prisoner in a public square. Convicts may suffer, even die and be tortured, but necessarily away from the public eye. Perhaps it is the sensitivity of a cynic and refined society that does not want to see the dirty side of the penalty. Likewise, today we are living in a time when animals are made to suffer the most in slaughterhouses, but it is also the era when the death and suffering of animals is shown the least. We hide the display of pain and as we do not see it, it is easier to believe it does not exist. ${ }^{10}$

\section{THE EFFECTS OF MODERN PRISON}

Modern criminology was born together with prison which, being a place of concentration of criminals, was the laboratory where they were observed, analysed, measured, photographed, drawn, catalogued, etc.

For the first time a subject-object of study was seen: the criminal.

Taking their observations as a starting point, answers explaining the difference between criminals and non-criminals were sought, taking it for granted that they did indeed exist.

Lombroso, ${ }^{11}$ as a scientist, founded the new positivist criminology, which believed in the determinism of human behavior with its inherently racist result and envisaged man (and in particular the criminal) not as a subject capable of making decisions, but as a predetermined subject.

Such theoretical analyses, despite giving a limited space to guilt, have always reassured the establishment as they consider the criminal an alien, a sick or abnormal person and not a product of society.

According to positivism, the criminal is different from us, inferior in the zoological ladder.

After the development of positivist criminology, the consequences of prison were studied, mainly on the prisoners, but also on their families, neighbors and society in general.

10 Cohen, Stanley, States of Denial. Knowing About Atrocities and Suffering, Malden (MA-USA): Columbia University, 2000.

11 Lombroso, Cesare, L'uomo delinquente in rapporto all'antropologia, alla giurisprudenza ed alla psichiatria. (cause e rimedi), Torino: Fratelli Bocca Editori, 1897. 
In the 1940 s, Clemmer, ${ }^{12}$ after having undertaken studies in North American prisons, named "prisonization" the process by which a prisoner acquires the values and habits of the prison, highlighting the criminal effects of prison.

In the 1960s, Goffman, ${ }^{13}$ who put prisons, psychiatric hospitals and other "total institutions"14 under the microscope, proposed the concept of deculturalization. It is also thanks to his empirical studies that scientific evidence was given, as sub results of imprisonment, of the presence of physical and mental health issues in the prisoners.

It was ultimately concluded that prison creates the criminal and can hardly help to re- socialize the convicts.

\section{MASS IMPRISONMENT}

Although the criminogenic effects of prison are well known and given the high costs of this sanction, it is not easy to explain why the use of prison sentence is still escalating in many countries. ${ }^{15}$

Trying to reduce criminality with prison - it may euphemistically be argued - is the same as trying to extinguish a fire with petrol.

The question we could ask ourselves then is whether, in the absence of an advantage for the community, there is a category that gains advantages from mass imprisonment.

In order to answer the question as to why mass imprisonment is taking place, it is essential to investigate its causes, both in the laws that generate it, as well as in the environment that allow its spread.

12 Clemmer, Donald, The Prision Community, New York, 1958.

13 Goffman, Erving, Internados. Ensayos sobre la situación social de los enfermos mentales: Buenos Aires: Amorrortu Editores, 1992, (Translated from English by M. Oyuela), p. 13.

14 With this expression, the author defines a place of residency or work, where a high number of people in the same situation, isolated from the rest of society for a certain amount of time, share, in the same condition of limited freedom, their daily habits formally regulated by an administration.

15 Garland, David, Mass Imprisonment: Social causes and consequences, London: Sage, 2001; Lacey, Nicola, American imprisonment in comparative perspective. Cambridge: Daedalus, 2010; Phelps, Michelle, The paradox of probation: Community supervision in the age of mass incarceration. Oxford: Law and Policy, 2013. 
Given the outrageous conditions of prisons, silence is an accomplice and it is the duty of the jurist to denounce, to protest and to seek responsibilities, since mass imprisonment, like slavery and torture, is not a natural phenomenon, but a social creation that can and must be changed.

I believe that, in order to understand the current global situation (or at least that in the West) of the high number of inmates, it is necessary to examine the case of the United States of America and understand how and why, since the 1970s, the number of people deprived of freedom has grown and reached such incredibly high levels.

In fact, the United States' penal policies have been to some extent imitated and indeed partly imposed on other countries. In other cases, although not a voluntary imitation, the adoption of similar policies in other sectors (e.g. with regards to social policies, the choice of strongly limiting them), has consequently led to State adopting a more punitive attitude. ${ }^{16}$

\section{Causes of mass imprisonment}

The rise in the level of imprisonment results from the difference between the number of individuals entering and exiting prison. If this difference is positive and, most importantly, is prolonged for a long time as a consequence of longer sentences, the number of prisoners will inevitably continue to increase.

It seems appropriate to divide the causes into two different groups. On the one hand the direct causes, on the other hand the non-direct.

Non-direct causes are sentences that send a convict to prison and laws stimulating the flow or making early release difficult. The non-direct cause in the United States is the war on drugs.

16 Garland, David, Castigo y sociedad moderna. Ciudad de México: Siglo XXI, 1999 (Translation from English by B. Ruiz de la Concha); Garland, David, (edited by), Mass Imprisonment: Social Causes and Consequences. London: Sage, 2001; Wacquant, Löic, Las cárceles de la miseria, Buenos Aires: Siglo XXI, 2000 (Translation from French di H. Pons); Wacquant, Löic, Parola D'onore: Tolleranza Zero. La trasformazione dello stato penale nella società neoliberale. Milano: Feltrinelli, 2000 (Translation from French di M. Guareschi); Wacquant, Löic, Simbiosi mortale, Neoliberalismo e politica penale. Verona: Ombre Corte, 2002 (Translation from English di A. De Giorgi). 
This has been the tool used as an electoral springboard by a great number of politicians. The story sold to the general public was the need to fight major crime syndicates that support drug traffic, but in reality it is a war waged mainly in poorer neighborhoods with a high percentage of black population.

In the American continent, as in Europe, drugs are consumed by a large portion of the population, especially by the young and university students. They, however, with very few exceptions, are rarely checked, as they are considered socially established individuals that do not raise particular suspicions. War on drugs in the United States has on the other hand marginalized categories in its sights, those that have no say.

Public opinion, for its part, has been persuaded, thanks to persistent media campaigns, that most drug users and dealers are black. Empiric studies demonstrate, however, that there is no real difference in the percentage of black or white drug traffickers and users (the black percentage being $15 \%$ ca.: i.e. more or less the percentage that they represent in the total population). Nevertheless, more than half of convicts are black. ${ }^{17}$

The direct causes, at a macro level, are mainly two.

The first is the dismantling of the welfare state.

In general, there is a correlation between the social state and the criminal state, in the sense that the increase of the criminal state appears inversely proportional to the decrease of the social state.

In the United States, the weakening of the ideal of resocialization must be analyzed as a specific outcome of a more widespread change: the reduction of the welfare and the glorification of the penal state. This change is linked to the adoption of neo-liberal economic regimes, meaning that social deregulation and growth of wage and labour precariousness have frequently appeared - and this is no mere coincidence - at the same time as the boom in the punitive or authoritarian state. ${ }^{18}$

Criticism towards the idea of the rehabilitation of the criminal has evolved. Right from the start, the right wing has strongly opposed spending public money on convicts. However, since the 1970s,

17 Alexander, Michelle, The New Jim Crow: Mass Incarceration in the Age of Colorblindness. New York: The New Press, 2010.

Wacquant, Löic, Simbiosi mortale. 
another - somewhat surprising - criticism has been added to the idea of rehabilitation by left wing groups. Some observed that the very idea of rehabilitation interpreted delinquency in a pathological key, allowing too intrusive interventions that caused an amplification of the punitive network (archipelago of punishments). ${ }^{19}$

Thus, a new criticism by/from the left wing was born against prison policies which proposed the transformation of people according to imposed values. ${ }^{20}$

An emblematic case is the one of Robert Martinson and his critical article What Works? Questions and Answers about Prison Reform, where the author strongly criticized the various rehabilitation programs carried out within prisons, mostly as they had no positive effect on recidivists rates. ${ }^{21}$ The article trigged a robust response even outside the scientific world, to which it was addressed, especially due to the idea that, as a perfect political slogan, it could be summed up into two words: nothing works. And as such, this idea was introduced into the political arena as a scientific topic (empirical) against the policies of rehabilitation, which ended up justifying a system that in reality was essentially focused on punishment.

Martison was all too familiar with being held behind bars as he was detained for 40 days in a maximum-security prison after taking part in a demonstration for civil rights.

Paraphrasing Pavarini, ${ }^{22}$ we could say that he knew prison in the facts and not just in the books. And it had been terrible for him to helplessly witness the misinterpretation of his work (especially the slogan nothing works) that ended up legitimizing the arguments of the right for the introduction of increasingly harsh criminal reforms.

19 Cohen, Stanley, States of Denial and Allen, Francis A., The decline of the Rehabilitative Ideal. New Haven (CO-USA), 1981.

20 A Clockwork Orange (Burgess's book as well as Kubrick's film) is a clear example of the liberal criticism to the politics aiming at the rehabilitation of criminals.

21 Martinson, Robert. What Works? - Questions and Answers About Prison Reform, in: http://www.pbpp.pa.gov/research_statistics/Documents/Martinson-What\%20Works\%201974.pdf, The Public Interest, 1974, pp. 35, 22-54.

22 PAVARINI, Massimo, Castigar al enemigo. Criminalidad, exclusion y marginalidad. Quito: Flacso, 2009, p. 127. 
Martinson later published other works arguing that he did not want to stimulate the rejection of rehabilitation policies, but simply criticize the way in which they were implemented, trusting in their improvement.

These, however, were not sufficient to out an end to the spread of the distorted interpretation of What Works?23

The second direct cause is the populism of a criminal political attitude fueled by the fear created by mass media.

The electoral success achieved by the Republican Party in the United States - by adopting a hyper-remunerative stance - also encouraged democrats to support and foment a punitive populist attitude. The last presidential candidate that opted for a position against the death penalty in the United States was Michael Dukakis in 1988, who lost a great deal of support precisely because of this stance.

Another sad example, although in the opposite direction, was Bill Clinton, who in 1992, in order to offer the mass media evidence of his inflexibility towards criminals, personally witnessed the execution of Ricky Rector, a mentally handicapped (and black) man. ${ }^{24}$

\section{IMPOSITION OF A HEGEMONIC ATTITUDE}

The mass imprisonment regime, as a pandemic, has expanded from the United States to the majority of western countries.

The example of the United States of America has been imitated in Europe - especially in the United Kingdom and Spain - and especially

23 The sense of guilt and emotional burden caused by the awareness of having unwillingly contributed to a sharp worsening of the conditions of imprisonment of many people, for whom he hoped instead for better treatment, were so strong, given the impossibility of stopping the spreading of the misinterpretation of his ideas, that they lead Martinson to suicide in 1980.

24 Rector was so very unaware of the world around him that he asked for the cake from his last meal to be set aside for the next day. Of little no or little use were the critiques to Clinton's opportunism also made to him by the New York Times Applebome, Peter, Arkansas Execution Raises Question on Governor's Politics, 25 January 1992. Available on http://www.nytimes. com/1992/01/25/us/1992-campaign-death-penalty-arkansas-execution -raises-questions-governor-s.html 
in Latin America, particularly in Chile, which, it is worth remembering, ranks among the least violent countries in the continent.

During the 1970s, only a few years were needed for a rapid change from a system that had placed its faith in resocialization to a remunerative one.

To counteract the adoption of these senseless policies, various scientific studies have to no avail clearly demonstrated the inconsistency of the idea that a higher rate of imprisonment is a consequence of an increase in crime. The relationship between crime and detainee figures, instead, is to say the least very weak.

Hence, the true causes of mass imprisonment are to be found in the political, democratic or authoritarian decisions taken by our society.

\section{The Chilean situation}

For the analysis of the situation in Chile, the study and comparison with the United States' system are essential, given that in the years of Augusto Pinochet's dictatorship Chile was forced to play the role of a real laboratory, in the economic and social fields, to the advantage of the North American country. ${ }^{25}$ Our question on mass imprisonment in the United States and Chile finds an answer in the respective national contexts, but also through the ideological bridge that connects - vertically - the two countries.

As occurred in the United States, in Chile hyper-retributionist criminal policies have also been implemented, with a substantial nullification of intramural social activities, for which a very reductive budget has been assigned.

It is not to be believed, however, that this represents prison during the Pinochet era and that now, a quarter of a century after the return of democracy, the situation has developed positively.

On the contrary, during the neoliberalist directorship imposed from 1973 to 1990, the levels of imprisonment were not so high, while figures began to upsurge during democracy.

25 Klein, Naomi, La doctrina del shock: El auge del capitalismo del desastre: Barcelona: Paidós, 2007, (Translation from English by I. Fuentes García). 
Chilean dictatorship was undeniably the most dramatic collective experience that the Chilean Republic had ever experienced. The public massacre and persecution of political enemies was of an unprecedented cruelty. The thousands persecuted, if they passed through prison, did not do so in the circuit reserved for common criminals: when they were not immediately executed, they were detained in circuits external and unrelated to the juridical system, before being executed, made to disappear or, at best, forced to exile.

Not counting political "delinquency", the number of common prisoners always remained stable. On the other hand, in the absence of elections, the crime question was always kept away from the political debate; furthermore, the regime could operate a strong censorship on mass media, which would certainly not deal with thorny issues such as crime or unemployment. As a consequence, public opinion's concern for common crime was far less during the dictatorship compared to the present.

It was, therefore, with the return to democracy that the crime issue entered political agendas and the punitive populism approach developed, resulting in an increase in penalties (especially for crimes against property and drug trafficking) following the approval of legislation passed almost unanimously by the social democratic coalition that had been in government for twenty years (until 2010) and by the conservative right.

If we take into consideration a relatively recent period of time and the environment in which the laws that have mostly influenced mass imprisonment were passed, it is clear that the causes of this phenomenon are to be traced to in the electoral process and the punitive language adopted during political campaigning.

Among the non-direct causes (the laws) the role of the protagonist was taken up by the reform of the criminal procedure law (year 2000) as well as by certain other provisions concerning substantive criminal law. ${ }^{26}$

26 Among the others particularly strict are the laws: 20.000 of 2005 that increases the penalties for drug trafficking: 20.580 of 2012 that increases penalties for drivers under the influence of alcohol: law $20 / 813$ by 2015 , about the control of weapons and ammunitions.

There is also a simplified procedure (article 406) applicable to offences for which the public prosecutor intends to request a sentence of 540 days or less. 
The new Chilean criminal procedure has replaced an archaic inquisitorial procedure with another, which is apparently more liberal. The semblance is reinforced by the large amount of financial investment made in restructuring the courts and modernizing them, including from an IT standpoint, improving standards to such as extent as to place Chile on a European level.

A liberal and modern appearance unfortunately hides an authoritarian structure which, with unprecedented speed and ease, within Chile's legal system, has filled its prisons with convicts.

The disproportion in the instruments available to the prosecution compared to the defense is evident: the vast majority of defendants in Chile cannot afford to pay a lawyer and is obliged to turn to professionals from the Defensoría Penal Pública (publics defender) who, although carrying out their work with credit, are overburdened with cases and do not receive adequate funding.

In an immediate response to the rapid increase in the number of detainees, moreover leading to prison overcrowding, social democrat governments have been building new, larger prisons, which have filled up quickly without resolving the problem of overpopulation.

On the other hand, negotiated justice and procedural incentives for the recognition of responsibility seriously contribute to mass detention in Chile. ${ }^{27}$ Also Italian law envisages practices such as plea bargaining and summary judgement; however, in Chile, they are hardly ever applied

On the basis of this, the defendant can acknowledge his liability in exchange for a discount.

These norms which, in the cases individually considered, "benefit" the offenders, in general, allow many persons to be condemned more easily and more quickly, without any contradictory judgement.

In particular, the procedimento abreviado (plea bargaining), envisaged by Articles 406 and following of the new Code, "rewards" the defendant who voluntarily accepts and recognizes their criminal responsibility. This way, the judge can impose a penalty of up to ten years without having to carry out a judgement in an adversarial procedure.

There is also a simplified procedure (Article 395 and following) applicable to crimes for which the prosecutor intends to ask for a punishment of up to 540 days. Persuant to this, the defendant can plead guilty in exchange for a reduction of the punishment. 
to avoid offenders being incarcerated, but rather to send them to prison more swiftly, as is the case in the United States. Furthermore, the laws that exceptionally increased the power of the public prosecutor and the police for specific serious crimes (terrorism, drug trafficking, etc.) have gradually become standard practice, threatening to expand to other areas of criminal proceeding.

Unfortunately, over the last twenty years in Chile we have witnessed the consolidation of a criminal state that has grown in a context of inequality, increasing segregation and neutralization of enemies.

Naturally, our interpretation is open to criticism and lends itself to counter-arguments, but one cannot fail to notice a strange interweaving of negotiations and connivance between the two coalitions that share political power in Chile, since they seem to defend similar interests on many issues.

These coincidences are visible when we try to provide an answer to questions such as: who promotes those reforms? Why is criticism towards those reforms so limited, almost non-existent?

Chilean doctrine has praised the liberal spirit of the reform of criminal procedure ${ }^{28}$ and we are certainly not nostalgic about the old inquisitive procedure. Unfortunately, few make any mention of its impact or its link with the hike in prisoner figures. ${ }^{29}$

We are of the firm conviction that mass imprisonment and an increasingly unequal social structure are intertwined. A fast and efficient criminal response is a perfect instrument of controlling the poor and unemployed masses. Regrettably, criminal law in Chile is complementary to the lack of a welfare state.

If we analyze the criminal, individual and social legal consequences of mass imprisonment in Chile, it is clear that it has paved the way to an increase in the criminalization of poverty.

These rules, that in single cases appear as "favouring" the perpetrators, however, on the whole allow to condemn more people in an easier and faster manner without an adversarial procedure.

28 Among those: Tavolari, Raúl, Instituciones del nuevo proceso penal: cuestiones y casos, Santiago de Chile: Jurídica, 2005; Horvitz, María Inés and López, Julián, Derecho procesal penal chileno, Santiago: Jurídica, 2002.

29 Cfr. Hernández, Alfonso, El nuevo régimen procesal penal chileno ¿Justicia para todos?, Valparaíso, 2002-2005. 


\section{Conclusions}

I strongly believe that a society with fewer prisons is possible and I am convinced that it is up to the doctrine to propose different solutions, punitive and non-punitive, to effectively address the problem of mass imprisonment. Without forgetting the electoral advantage of punitive populism, I believe the option is vital, for Chile, of non-custodial sentences for crimes of medium or low seriousness, a reduction of the edictal limits of custodial sentences and the decriminalization of many forms of conduct which today are considered crimes, while resorting to administrative sanctions.

In Chile, unfortunately, there is a total lack of empirical studies on the subject of criminal policy, which makes it extremely difficult to verify hypotheses and theories, thus compelling the interpreter to work on the basis of intuitions or rely on the hypothetical usability in the national context of theories developed abroad. This method however, is liable to distort any analysis, because the social context and prison have specific features that cannot be overlooked. Furthermore, we must bear in mind that Chilean prisons are administrated in a very rigid manner and officials, at a local as well as national level, are reluctant to agree on programs or projects that allow an understanding of what really happens inside them and what the real conditions of the detainees are like.

To end our discussion, we cannot lose track of the concept of the individual as a person, that should be our polar star. We should observe carefully how much our society views the person as an end or as a means and if it considers the person's essence to be inviolable or not.

We cannot forget that conceiving prison is conceiving the punishment and conceiving the punishment is conceiving the human being.

Laws, whose main objective is to regulate personal conduct, must be consistent with each other and comply with the fundamental principles of minimum criminal law intervention. Fatal events, such as the death of prisoners in jail because of fire, murder or ill-treatment by other prisoners, torture, xenophobic laws disguised as anti-terrorist laws, among other things, cast doubt on the respect for human rights in Chile today.

In a context such as the modern one, in which politicians seem to be more attentive to the compulsive instincts of citizens rather than to their higher aspirations, this will appear to be blasphemy. 
However, we wish to highlight the fact that the problem of prison should be solved by listening to the need of the prisoners themselves. We cannot accept that a prisoner as such is considered a non-citizen. The best option will never be to improve a savage and violent institution such as prison, rather, on the contrary, to think less and less in terms of prison and seek for real strategies for its containment. Thereby to gradually reduce imprisonment, in order to eliminate it completely.

In conclusion, we believe it is vital to remember that imprisoning a person is a violent act, which involves the constraint of a body in a small dehumanizing space.

By dehumanizing another human being, we dehumanize ourselves and mass dehumanization naturally leads to the dehumanization of society. It cannot be otherwise, even if we do not directly know the pain of prisoners. Mass imprisonment, like a silent ghost, undermines the freedom of all of us and ends up taking away the most precious part of life itself.

On the other hand, the criminal effects and the costs of mass incarceration will be paid in the future with an increase of crime and violence, leading unavoidably to a higher number of prisons, more controls and more policemen and more prisoners. Thus, mass imprisonment, like a spiral, leads to prison for all of us. Only a change of direction, a shift towards respect for human dignity, can help us prevent such a suicidal policy.

\section{REFERENCES}

ALEXANDER, Michelle, The New Jim Crow: Mass Incarceration in the Age of Colorblindness. New York: The New Press, 2010.

APPLEBOME, Peter, Arkansas Execution Raises Question on Governor's Politics, 25 January 1992. Available on http://www.nytimes.com/1992/01/25/us/1992-campaign-death-penalty-arkansas-execution-raises-questions-governor-s.html

CAVADINO, Michael, Mick CAVADINO and DIGNAN, James Penal systems: A comparative approach. London: Sage, 2005.

CLEMMER, Donald, The Prision Community, New York, 1958.

COHEN, Stanley, States of Denial. Knowing About Atrocities and Suffering. Malden (MA-USA): Columbia University, 2000.

CUNEO, Silvio, Cárceles y Pobreza. Distorsiones del populismo penal. Santiago de Chile: Uqbar editores, 2018. 
FOUCAULT, Michael, Vigilar y castigar: nacimiento de la prisión. Mexico: Siglo XXI, 2002, (Translated from French by A. Garzón del Camino).

FOUCAULT, Michael, Vigilar y castigar: nacimiento de la prisión. México: Siglo XXI, 2002, (Translated from French by Garzón del camino, Aurelio).

GARLAND, David, Castigo y sociedad moderna. Ciudad de México: Siglo XXI, 1999 (Translation from English by B. Ruiz de la Concha).

GARLAND, David, The Culture of Control. Crime and Social Order in Contemporary Society. Chicago: University of Chicago Press, 2001.

GARLAND, David, (edited by), Mass Imprisonment: Social Causes and Consequences. London: Sage, 2001.

GOFFMAN, Erving, Internados. Ensayos sobre la situación social de los enfermos mentales. Buenos Aires: Amorrortu Editores, 1992, (Translated from English by M. Oyuela).

GRANDE, Elisabetta, Il terzo strike. La prigione in America. Palermo: Sallerio Editore, 2007.

GRANDE, Elisabetta, Guai ai poveri. La faccia triste dell'America. Torino: Edizione GruppoAbele, 2017.

GUZMÁN DÁLBORA, José, La pena y la extinción de la responsabilidad penal. Santiago de Chile: Legal Publishing, 2008.

HERNÁNDEZ, Alfonso, El nuevo régimen procesal penal chileno ¿Justicia para todos?. Valparaíso, 2002-2005.

HORVITZ, María Inés; LÓPEZ, Julián, Derecho procesal penal chileno. Santiago de Chile: Jurídica, 2002.

KLEIN, Naomi, La doctrina del shock: El auge del capitalismo del desastre. Barcelona: Paidós, 2007, (Translation from English by I. Fuentes García).

LACEY, Nicola, American imprisonment in comparative perspective. Cambridge: Daedalus, 2010.

LOMBROSO, Cesare, L'uomo delinquente in rapporto all'antropologia, alla giurisprudenza ed alla psichiatria. (cause e rimedi). Torino: Fratelli Bocca Editori, 1897.

MARTINSON, Robert. What Works? - Questions and Answers About Prison Reform, in: http://www.pbpp.pa.gov/research_statistics/Documents/Martinson-What\%20 Works\%201974.pdf, The Public Interest, 1974, pp. 35, 22-54.

MELOSSI, Dario; PAVARINI, Massimo, Carcere e fabbrica. Alle oringini del sistema penitenziario (XVI-XIX secolo). Bologna: Il Molino, 1978.

PAVARINI, Massimo, Castigar al enemigo. Criminalidad, exclusion y marginalidad. Quito: Flacso, 2009. 
PHELPS, Michelle, The paradox of probation: Community supervision in the age of mass incarceration. Oxford: Law and Policy, 2013.

RUOTOLO, Marco (a cura di), Il senso della pena. Ad un anno dalla sentenza Torregiani della Corte EDU. Editoriale Scientifica: Napoli, 2014.

RUSCHE, Georg; KIRCHHEIMER, Otto, Pena y estructura social. Bogotà: Temis, 2004, (Translated from English by E. García Méndez).

TAVOLARI, Raúl, Instituciones del nuevo proceso penal: cuestiones y casos. Santiago de Chile: Jurídica, 2005.

WACQUANT, Löic, Las cárceles de la miseria. Buenos Aires: Siglo XXI, 2000 (Translation from French di H. Pons).

WACQUANT, Löic, Parola D'onore: Tolleranza Zero. La trasformazione dello stato penale nella società neoliberale. Milano, 2000 (Translation from French di M. Guareschi)

WACQUANT, Löic, Simbiosi mortale, Neoliberalismo e politica penale. Verona, 2002 (Translation from English di A. De Giorgi).

\section{Informações adicionais e declarações dos autores (integridade científica)}

Agradecimentos (acknowledgement): Michelle Barranger, para a revisão final do artigo.

Declaração de conflito de interesses (conflict of interest declaration): o autor confirma que não há conflitos de interesse na realização das pesquisas expostas e na redação deste artigo.

Declaração de autoria e especificação das contribuições (declaration of authorship): todas e somente as pessoas que atendem os requisitos de autoria deste artigo estão listadas como autores; todos os coautores se responsabilizam integralmente por este trabalho em sua totalidade.

Declaração de ineditismo e originalidade (declaration of originality): o autor assegura que o texto aqui publicado não foi divulgado anteriormente em outro meio e que futura republicação somente se realizará com a indicação expressa da referência desta publicação original; também atesta que não há plágio de terceiros ou autoplágio. 


\section{Dados do processo editorial}

(http://www.ibraspp.com.br/revista/index.php/RBDPP/about/editorialPolicies)

- Recebido em: 31/12/2018

- Controle preliminar e verificação de plágio: 08/01/2019

- Avaliação 1: 09/01/2019

- Avaliação 2: 15/01/2019

- Avaliação 3: 20/01/2019

- Decisão editorial preliminar: 20/01/2019

- Retorno rodada de correções: 22/01/2019

- Decisão editorial final: 29/01/2019
Equipe editorial envolvida

- Editor-chefe: 1 (VGV)

- Editor-associado: 1 (ELL)

- Revisores: 3

\section{COMO CITAR ESTE ARTIGO:}

CUNEO, Silvio. The inmate as a victim of the rise in the incarceration rate and the perception of insecurity in western society. A particular analysis of the Chilean case. Revista Brasileira de Direito Processual Penal, Porto Alegre, vol. 5, n. 1, p. 93-114, jan./abr. 2019. https://doi.org/10.22197/rbdpp.v5i1.217

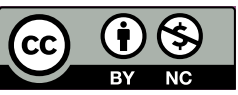

Esta obra está licenciada com uma Licença Creative Commons Atribuição-NãoComercial 4.0 Internacional. 